\title{
通勤鉄道の都心到達時間による 都市人口の推移の考察
}

\author{
柴垣 寛 1 \\ '正会員 東武計画株式会社 技師長 （广131東京都墨田区向島 1丁目32-3）
}

\begin{abstract}
本研究は首都圈における通勤鉄道の開発に際して，その採算性に大きく影響を与える定住人口の予測を 数量的に求めるために, 都心への通勤時間や，そのほかの要因について重回帰分析法によつて解析をおこ なったこれらの要因を用いると，沿線の都市の人口の推移が実際の変化とよく適合し予測が可能となった これを応用することによって通勤鉄道の採算性を向上するための方策として，通勤鉄道は線形の改良や速 度向上などによって都心への到達時間の短縮をはかれば, 沿線居住人口の増加と利用客の増加の程度を数 量的に予測されるようになって，通勤鉄道の採算性に寄与することを数量的に確かめられるようになった。
\end{abstract}

Key Words:commutation railrord, population density by commutation time, multiple regression analysis with weight

\section{1.はじめに}

大都市圈において通勤・通学のために利用されている 近郊鉄道は地域に多大の便益を供すると同時に，その運 行速度の向上といった効用によって，沿線の都市の定住 人口に多大な影響を与えている. この種の鉄道は沿線の 定住人口によって輸送需要が大きく影響を受けているた め，採算性の検討には，運行速度の向上によって増加が 予測される沿線の定住人口の経年の変化を求めることが 大切である. 既に都市の定住人口の変動については様々 な角度から分析がなされているが，本研究では考える範 囲にわたつて予測した総人口を配分し，解析をするもの とは異なって，輸送手段としての近郊鉄道の運行速度が 沿線都市の定住人口にどのような経過で数量的な変化を もたらしているかを線区単位で予測することを目的とす る.

これには沿線の定住人口を人口密度で考えることが望 ましく, 人口密度を都心迄の距離によって表すC.Clark の密度関数 ${ }^{1)}$ によって解析する方法もあるが，本研究で は人口密度に大きな影響を与える因子として都心までの 時間距離であることが既に発表 ${ }^{2)}$ されていて, 時間距 離を用いた解析方法が実情にたいしてあてはまりが良い ために時間距離を第一の要素として検討する. しかし大 都市圏内の人口の分布とその経年変化を表すためには都 心までの時間距離だけでは都市交通の輸送改善といった 条件の変化を反映させるには不十分であるので，他に都
市の面積，鉄道線路数を変数として考慮して都市の人口 密度の分布と経年変化を重回帰分析法によって検討する.

都市の人口密度の (時系列) 変化については国沢 · 堀 部のデータ貼り合わせ法によって解析 $\left.{ }^{3}\right)$ された例も報告 されていて，人口密度の経年変化について時系列をずら して重ね合わせることによって求めている.この時系列 によって求めた都市の人口密度については衰退・急増・ 飽和・過飽和・その他の 5 項目にわけて論じてあるが, その現象の原因については触れられていない. 本研究で は通勤鉄道の沿線の人口密度は都心への輸送条件である 都心迄の到達時間と鉄道線路数等の社会情勢によって変 化しているという観点にたっているため，そのままでは 応用が困難である.

また都市の人口密度については鉄道が整備されること によって，鉄道沿線の自治体単位の人口の伸びは長期間 のデータの解析によって，正の相関4)があることと，そ れとは別に都心部における居住人口は，ある経過年数後 には飽和状態になって静止状況, または减少に向かって いることは既に発表 ${ }^{3)}$ されている.このような人口の変 化の原因には触れられていないため, 鉄道の運行速度の 向上によるものか，否かは明らかではない。

都市の人口密度が年数の経過に伴って徐々にある種の 均衡状態である飽和人口密度に接近する考えは既に都市 の人口の推移を実際にロジステック曲線をあてはめて検 討をした例 ${ }^{5}$ が報告されているが，鉄道の運行速度の向 上といった都市の動的な変化の影響には触れられていな 
い.

また都市は年数の経過にともなって人口が増加し，や がて停滞し, 減少に向かっていく場合がよく見受けられ るが，この点については人口の社会增加率の観点から人 口密度は平淮化されるとして都心部の减少と郊外部の増 加の傾向を説明6)している. これについては都市の与え られている条件の変化（例えば都心までの到達時間の短 縮）による影響について触れられていない．

本研究では都市の与えられている条件の変化として, 都心までの到達時間や鉄道線路数が大きな影響を持ち, さらに社会情勢の変化も数量的にあらわすことの可能性 を追求したものである.これによって求めた都市の人口 の予測は鉄道の経営改善の判断に必要な数値を与えるも のである.

\section{2. 都市人口の変化の状况}

\section{（1）通勤鉄道と沿線都市定住人口}

首都圈においては第二次大戦後，人口の集中に伴って 業務活動のための輸送機関として通勤・通学鉄道の役割 は大きく, その改良, 建設がなされている. しかし初期 投下資本が多額のため, その整備状況はなかなか進渉を みていない．しかも鉄道運賃が政策的に抑えられている こともあって，鉄道事業者はその採算性を確保するため に苦慮している. 一方社会資本整備の観点からは, 都市 近郊鉄道を建設することによって, 地域の開発が期待さ れている. しかし鉄道新線そのものの採算性を向上させ る具体的方策として考えられている鉄道運行速度の向上 による輸送量の増加の数量的な解明は十分ではない. 通 勤・通学輸送を担う大都市圈鉄道の速度向上による鉄道 旅客の増加の予測については, 昭和40年前半頃までは輸 送改善としては線路増設や車両編成両数の増大, 列車増 発に重点がおかれ列車の運行速度の向上までは手が回ら なかったため, 運行速度の向上による輸送量の変化につ いては，実績值が少なく比較するデータが少なかった.

しかし, 昭和40年代になって首都圈の通勤鉄道の整備も 進み, 輸送改善の際に運行速度の向上が図られた区間が でてきて鉄道運行速度の違いを示すようなデータも揃っ てきている.

第二次大戦の終了後日本経済の発展と共に首都圈の人 口は伸び率に変化はあるものの一貫して増加している. しかし，個々の都市についてみると昭和40年代に入るま で緩やかな増加や減少を示している都市もあれば, ある 時点から突然に著しい増加傾向に転じた都市もある. そ の傾向については、昭和39年より住民登録による定住人

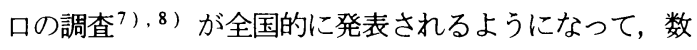
字的に明瞭になってきた. 一方東京都心については昭和 50 年頃より定住人口については増加が頭打ちとなりさら
に以後の人口は徐々に减少しその傾向が止らない区域も ある. その理由として都心における業務要請の増加に よって居住条件が悪化し, 昼間人口は著しく増加しなが ら定住人口（夜間人口）が減少している.

首都圈における通勤・通学人口は都心に向からて流動 しているが, 一ヶ所に集中しているわけではない. 都心 の考え方として従業地中心をとって外㨉通勤密度を用い る例1)あるが，ここでは都心として広がりをもった地 域を考える. 東京都の昭和45，50，55年の国勢調査 ${ }^{9}$ に よると, 都の中心部の千代田, 中央, 港, 新宿, 文京, 台東, 墨田, 江東, 品川, 渋谷, 豊島の11区は昼間人口 が定住人口である夜間人口を上回っている. これらの各 区には業務機関及び教育機関が多く存在し，これらに 通ってくる人口が多く, 都心業務機能を果たしていて, 都心を形成している地域とみなすこととする. 本研究で は都市までの到達時間として仮想中心を用いずに，これ らの各区をほぼ井む J R山手環状線の各駅と, 東側の浅 草, 押上, 錦糸町, 東陽町の各駅を都心入り口駅とし郊 外の都市からの鉄道の到達時間をパラメータとして用い る. これらの各駅はターミナル機能を持ち, 通勤用の急 行電車, 快速電車などの停車駅となって, 通勤・通学者 はこれらの駅を経由してそれぞれの目的地にむかってい る. 従ってこれらの都心内部の交錯する交通需要は別個 のものとみなし, 本研究から除いて考える.

そこで大都市を中心として周辺に位置する集落・地域 を自治体ごとに一つの単位として衛星都市 ${ }^{10}$ ) と定義を する. これは一部に用いられている職住を一体化して, 大都市とは独立している都市を示すものとは異なってい る. 首都圈のこれらの衛星都市については昭和 40 年代後 半になるとその増加傾向が頭打ちとなって緩やかな増减 を繰り返している都市もあれば, 都心への通勤条件の改 善として, 線路新設, 増設, 鉄道運行速度の向上によっ て都心への到達時間の短縮がなされ, 居住人口の増加傾 向が上向きになっている都市もある. この点については 鉄道が整備されることによって, 鉄道沿線の自治体単位 の人口の伸びは, ある経過年数後には飽和状態になっ て静止状況, または减少に向かっていることは, すでに発 表3)されている.

この通勤条件の改善による沿線の人口推移については, 通勤鉄道の線路増設による輸送力の増強をはかられたが， 通勤時間の短縮がさほどはかられなかった線区と, 輸送 改善によって通勤時間の短縮がはかられた線区によって 大きな差異があることは，既に発表11) したとおりであ る.

\section{（2）衛星都市の人口の推移の形}

首都圈における通勤鉄道の建設や改良を計画する際に, 将来人口の推移の予測が重要な項目の一つである. 都市 
の定住人口としては住民登録人口がそれに相当している ので過去のデータを調べてみる．衛星都市の住民登録人 口は地域の開発や都心へのアプローチの改善，あるいは 居住条件の変化によって増加したり，减少したり，ある いは変化の少ないといった様々な状況を示している．人 口の推移を時系列としてとらえると, 現在では指数曲線 とされ増加にしろ減少にしろ数式的に示されるとされて いる.

指数曲線としては修正指数曲線, 成長曲線, ロジス ティック曲線5)等も予測に用いられている. 定住人口の 予測には, 社会的な観点から居住可能なある極限值が存 在し，かつそれが既知であるならば応用することは適当 と考えられる.しかし，都市の定住人口の極限值は簡単 には求められないし，極限值についても都市の内的ある いは外的条件の変動によって変化していると推測される. しかし，ある時点では都市の与えられた条件のもとで, 居住可能な人口には極限値が存在しているものと仮定し, その極限值を飽和人口と見做し，その時の人口密度を飽 和人口密度と仮称し, 都市の人口密度は年数の経過に 従って飽和人口密度に接近すると仮定する. この際衛星 都市の人口密度に影響を与える大きな因子として都心ま

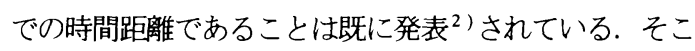
で衛星都市から都心入り口駅までの到達時間を $\mathbf{t}^{12)}$ と し, 衛星都市のゾーン中心として自治体庁舎の最寄り駅 または急行電車や快速電車の停車駅（多くの場合一致し ている）から都心入り口駅として J R山手環状線上の各 駅及び浅草, 押上, 錦系町の各駅をとり, 平日の朝の通 勤時間帯の急行電車など速度の高い電車の運行時間を用 いる.

この $\mathbf{t}$ については費用としての運賃を考え, 一般化 費用として考察することもあるが，現在通勤費用が使用 者負担が殆どである点から，通勤旅客の経路の選定には 通勤時間の最短を主としているため, 時間に限って検討 を進める.

\section{（3）ロジスティック曲線のあてはめの実例}

都市の人口密度が飽和人口密度に接近する考えは既に 衛星都市の人口の推移を実際にロジステック曲線をあて はめて検討をした例13) が報告されている．そこで首都 圈においていくつかの衛星都市を選びロジスティック曲 線をあてはめて計算し，実例と比較をした，期間につい ては住民登録の制度が確立し統計がそろいだした昭和 39 年から平成 4 年までの住民登録人口調査 ${ }^{7), 8)}$ より人口 密度を求めて試算をおこなった。 サンプルとしては人口 密度については東京の都心に近く緩やかな変動を示して いる都市として東京都杉並区，都心より離九比較的はや くに増加を示した都市として東京都立川市，時間的に遅 れて急激に増加を示した都市として千葉県柏市を選んだ.
ロジスティック曲線のあてはめは, 次の式 $\left.{ }^{14}\right)$ にっ た.

$$
y=\frac{a}{1+m \exp (-b x)}
$$

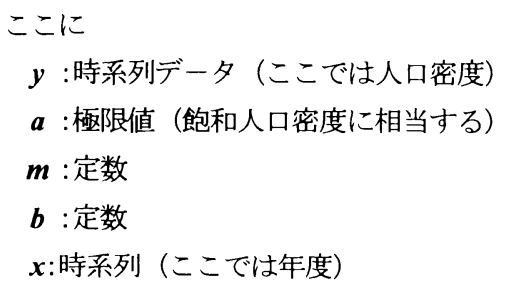

である.この式を $\boldsymbol{x}$ について微分し, 単回帰の式に変 換してこれらの定数を求めるのであるが，その際，時系 列のデータは差分の形でもとめることが推奨され, 差分 の取り方として中点差分法を用いた. 各都市の人口密度 は公表された住民登録と都市の面積 $\left.{ }^{15}\right)$ により求めた. この数值を用いて昭和 39 年から平成 4 年の全体の 29 のデ 一タでロジスティック曲線をあてはめて極限值である $a$ を求めると

$$
\begin{array}{ll}
\text { 杉並区 } & \begin{array}{l}
15633 \text { 人 } / \mathrm{km}^{2} \\
\text { 立川市 }
\end{array} \\
\text { 柏 市 } & \text { 6751人 } / \mathrm{km}^{2} \\
& 4516 \text { 人 } / \mathrm{km}^{2}
\end{array}
$$

となる. 昭和59年を例として㬰際の人口密度と予測值 としてのロジスティック曲線の極限值 $\boldsymbol{a}$ との差を, 将 来の人口密度の増加可能量とすると, 杉並区については 全体 29 データの平均值 15512 人 $/ \mathrm{km}^{2}$ と差は少なく, 現在 の条件では人口の増减が少ない人口の静止状態の都市と 考えられる. しかし, 立川市と柏市とを比べてみると, 通勤輸送条件の改善が著しく将来の成長の可能性が大き いと思われる柏市は人口密度の増加可能量は約 300 人 $/ \mathrm{km}^{2}$ であるのにたいして，通勤輸送条件の改善としては 都心への到達時間の短縮や線路の増設が行われなかった 立川市は, 人口密度の増加可能量が大きくないと予想 されるが，それにもかかわらずに柏市より大きい約 450 人 $/ \mathrm{km}^{2}$ となっている. さらに念のために予測式とし てロジスティック曲線を用いて人口密度の極限值を求め ることが適当か否かを検討をしてみる. 人口密度の予測 としてはロジスティック曲線のスタートの時点も変曲点 もわかっていない状態冺出発すると考えて, 人口密度 の年次変化曲線の任意の点から10年毎に区切ってロジス ティック曲線を求める. 各都市について昭和39年から昭 和50年まで, 昭和 40 年から昭和 51 年まで, と以下同様に して 12年間のデータ（差分を用いるため前後1年ずつの 
データを加味するため実際は10個のデータとなる）を 1区分ずつに区切つて極限值である $a$ を求めると，図一

2.1 杉並区の極限值 $\boldsymbol{a}$ の推移 (14487〜 16823人 $\left./ \mathrm{km}^{2}\right)$, 図-2. 2 立川市の極限值 $\boldsymbol{a}$ の推移（-77109～11384人 $/ \mathrm{km}^{2}$ ), 図-2.3 柏市の極限值 $\boldsymbol{a}$ の推移 (3746〜 10141人 $\left./ \mathrm{km}^{2}\right)$ のようになる．ただし，立川市のマイナスの数值 については極端に大きい値を示すため10分の1に縮小し てある. 図-2.1〜3 の示すように，データによっては変 動が大きくあらわれている.これは非線形な連続関数で ある微分方程式を解くときに，時系列データを差分方程 式に変換して解を求め, 連続曲線を離散化したためおき る現象と説明 16$)$ されている. またロバート・メイが 1973年にロジスティック曲線の数值実験 ${ }^{17)}$ を試み, 或 る条件のもとで，解が大きく上下に摇れ動くことが示さ れている。

そこで期間を長期に取って22年分のデータで同じ様に 試算してみると立川市の例ではマイナスの数值はないが 6164〜16653人 $/ \mathrm{km}^{2}$ と依然として変動が大きい，杉並区

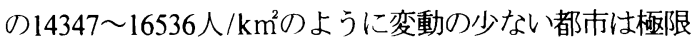
值 $\boldsymbol{a}$ については変動が少なく適用は可能と考えられる しかし，幻影解17）１8）の存在が指摘され，条件によっ ては数值が大きく変動しているので, ロジスティック曲 線の適用による極限值を求めることは一考を要する.こ れは人口密度の経年曲線のように理論曲線にたいしてゆ れがある場合には差分方程式に変換する際の構造的な問 題もある．たとえ時系列データを長期間とれば適用が可 能としても，時系列が長くなるとその間に都市の発達や 内的外的条件の変化が予想されるため，立川市や柏市の ように人口密度が成長過程にある都市についてはそのま ま使うのは無理がある.このような点から首都圈におけ る衛星都市の人口密度をロジスティック曲線を用いて将 来の極限値である飽和人口密度を推定することは無理な ことと判断し，別のアプローチを考えることとする.

\section{3. 飽和人口密度}

\section{（1）衛星都市の飽和人口密度の算定}

首都圏の衛星都市の人口の変遷を検討するにあたって 昭和60年代に起こったバブル経済の影響によって急激な 都心人口の减少や極端な遠距離通勤による人口の郊外 の移動等の現象については，今なお調整期とみられるの で昭和59年までのデータを中心として解析をすることに する. 昭和59年から 10 年さかのぼり衛星都市の昭和49年 からの10年の人口の変遷をみると，あまり大きく変動を していない都市が幾つか存在している. 少ない変動を示 している都市は, 首都機能への通勤, 通学などがその都 市の特性としてある種の平衡状態にあると考えて，そ

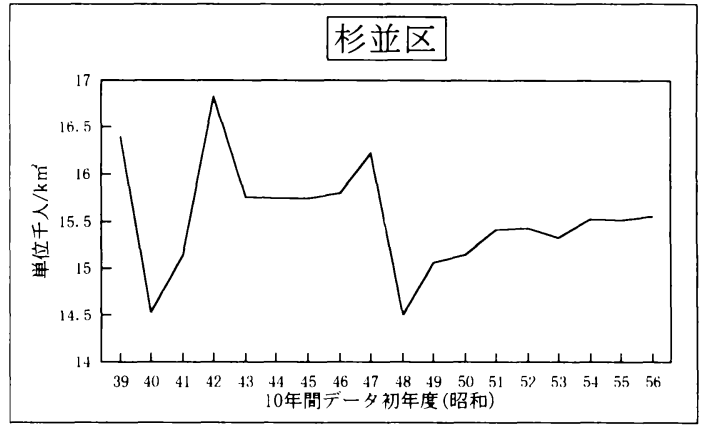

図-2.1 杉並区の極限値 $\boldsymbol{a}$ の推移

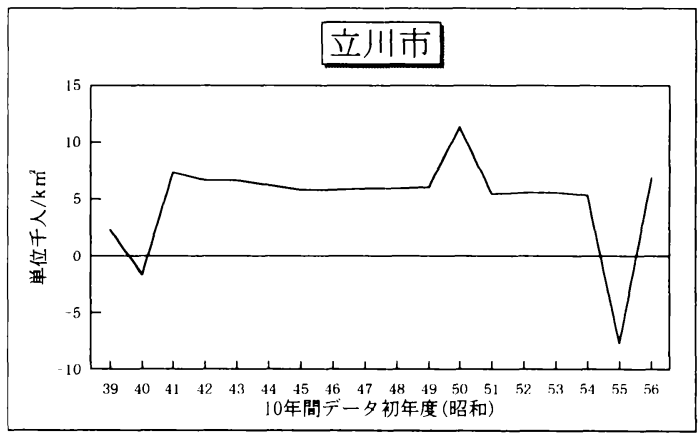

図-2. 2 立川市の極限値 $\boldsymbol{a}$ の推移

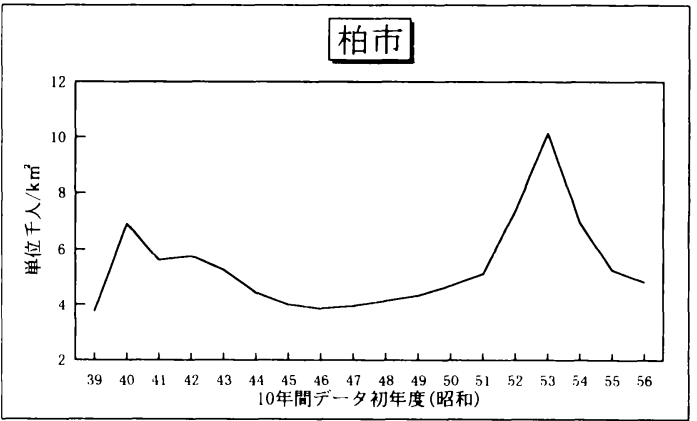

図-2.3 柏 市の極限値 $\boldsymbol{a}$ の推移 
の状態の定住人口が衛星都市の飽和人口密度になったと 仮定をする.

昭和 49 年から昭和 59 年の 10 年間に増加率を上方，下方 ともに $10 \%$ の範井の変動值に収まっている首都交通圈 内の衛星都市を拾いだすと, 次の38市区の都市となる. 東京都 新宿区, 目黒区，世田谷区，渋谷区，中野区， 杉並区，板橋区，練馬区，足立区，葛飾区， 江戸川区，立川市，武蔵野市，三鷹市，調布市， 小金井市，小平市，国分寺市，国立市，田無市， 保谷市，狛江市，清瀬市

神奈川県 横浜市 神奈川区，南区，保土ヶ谷区， 磯子区，金沢区，港北区

川崎市 幸区，中原区，

鎌倉市，逗子市，三浦市

埼玉県 飯能市，与野市，烣市，上福岡市

これらの38都市について，基準の年として昭和59年を 選び，都市の人口密度に相関を持っている項目として考 えられる次の10項目を選んで飽和状態にある都市の人口 密度の相関行列を求めた.

(1) 都市の人口 $=\mathbf{N}_{59}$

(2) 都市の人口密度 $=p_{59}$

（3）都心までの到達時間（分） $=\mathbf{t}$

（4）都市の面積 $\left(\mathrm{km}^{2}\right)=\mathbf{M}$

（5）都市区域内鉄道線路数（区域内通過線路数は1, 起 終点は0.5) = n

（6）都市区域内鉄道線路数当り面積 $=M / n$

（7）昭和 49 年迄の 10 年間の人口の過去伸率 $=\mathbf{r}$

（8）昭和59年の都市人口密度の自然対数 $=\log \left(p_{59}\right)$

（9）各都市の面積の平均に対する比率 $=\mathbf{M} / \mathbf{g}$ (gは衛 星都市の平均面積 $\left(7.688 \mathrm{~km}^{2}\right)$ )

(10) 都市の面積の二乗 $=\mathbf{M}^{2}$

これらの10項目の相関係数行列は各項目の間で互いに 独立しているものばかりではないので，得られた相関行 列を検討した結果，(2),(3),(4),(5)の各項目を選んで 重相関分析をおこなうことを検討する.これらの項目の うち都心到達時間 $\mathbf{t}$ については, 首都圈における通勤 - 通学の輸送量は最大值を示す平日の朝の通勤時間帯に おいて圧倒的に都心方向に向かう量が多いため, 都心に 向かう1方向を基準とした. 都市の人口分布は駅の数が 大きな因子19)であるが，駅の数は輸送要請の増加に よって適時増設されて, 中長期の間には駅の数が増える ことが多い.さらに駅の数は都市内の線路数によっても 左右されることを考慮に入れて都市区域内の線路数を用 いた. 都市区域内の線路数については区域内を貫通して いるものを1とし, 区域内で起終点になっているものは 貫通しているものに比べて区域内発生の輸送要請の片側 方向を主に担っていることを考えにいれて0.5とした. 基淮変量として人口密度が時間距離の対数で計算するこ
表-3. 1 都市人口密度関連相関行列

\begin{tabular}{|c|c|c|c|c|}
\hline & $\log \left(\boldsymbol{p}_{\text {59 }}\right)$ & $\mathbf{t}$ & $\mathbf{M} / \mathbf{n}$ & $\mathbf{M}$ \\
\hline $\log \left(\boldsymbol{p}_{\text {s9 }}\right)$ & 1.0000 & -0.8718 & -0.0863 & -0.5942 \\
\hline $\mathbf{t}$ & & 1.0000 & 0.6253 & 0.2373 \\
\hline $\mathbf{M} / \mathbf{n}$ & & & 1.0000 & 0.7117 \\
\hline $\mathbf{M}$ & & & & 1.0000 \\
\hline
\end{tabular}

とが適当であるので昭和59年の人口密度の自然対数をと ることとした．通勤・通学鉄道の各線区を別々にみると 線区ごとの計算では定数項は不揃いであるが統合して計 算することにより，線区を統一して表せるように考える. なお (7) 項の昭和49年以前の10年間の過去伸率は相関 関係が低いので検討から除外し，分析に用いた数值は 表-3.1 都市人口密度関連相関行列 である. これらを 用いて以下のようにいくつかの予測式を想定した

$$
\begin{aligned}
& \boldsymbol{p}_{59}=\mathrm{A} \exp (\mathrm{B} \mathbf{t}+\mathrm{C} \mathbf{M}) \\
& \boldsymbol{p}_{59}=\mathrm{A} \exp (\mathrm{B} \mathbf{t}+\mathrm{C} \mathbf{M}+\mathrm{D} \mathbf{n}) \\
& \boldsymbol{p}_{59}=\mathrm{A} \exp \left(\mathrm{B} \mathbf{t}+\mathrm{C} \mathbf{M}^{2}+\mathrm{D} \mathbf{n}\right) \\
& \boldsymbol{p}_{59}=\mathrm{A} \exp (\mathrm{B} \mathbf{t}+\mathrm{C}(\mathbf{M} / \mathbf{n})) \\
& \boldsymbol{p}_{59}=\mathrm{A} \exp (\mathrm{B} \mathbf{t})(\mathbf{M} / \mathbf{n} / \mathbf{g})^{\mathrm{C}} \\
& \boldsymbol{p}_{59}=\mathrm{A} \exp (\mathrm{B} \mathbf{t}) \mathbf{M}^{\mathrm{C}} \mathbf{n}{ }^{\mathrm{D}} \\
& \boldsymbol{p}_{59}=\mathrm{A} \exp (\mathrm{B} \mathbf{t})(\mathbf{M} / \mathbf{n})^{\mathrm{C}} \\
& こ こ に
\end{aligned}
$$

$\mathrm{A}$ : 定数, $\mathrm{B}$ : 定数 , $\mathrm{C}$ : 定数

である.

上記7式を用いてはじめに首都圈内38都市につて重相 関分析 ${ }^{20}$ ををおこなった結果, 重相関係数 $\mu$ は 0.8798 か ら0.9299 までで予測值を求めるには, ある程度の誤差を 認めて用いることとする.

前回 ${ }^{11)}$ は式 (3.1e)で計算をおこなったが，重相関倸 数 $\mu$ は0.8798 であって, 予測式のなかで最も小さい值 を示した. ただ，どの予測式においても，横浜市南区の 予測值は大きくはずれている. そこで38都市の飽和人口 密度の重相関分析の結果求められた予測值と実績值との 偏差を算出し, 標準偏差を計算すると, 横浜市南区につ いてのみはこの標準偏差の 3倍を超過する偏差を示して いる. データが正規分布をしていると仮定した場合には 標準偏差の 3倍を超過するデータについては母集団とは 異質とみなすことが通常行われている.このため, 南区 を除いてあらためて37都市について計算をおこなった。

これによってあらためて相関行列を求めたものが 表 -3.1 都市人口密度関連相関行列 である. その結果最 も重相関係数の高かったのは，式(3.1c) で 0.971 であ り，低かったのは式(3.1e)で0.914 であった. しかし実 際に応用する場合を考えると, 面積の項が二乗の形で 入っている場合は, 同じ面積で同じ線路数の都市を組み 
合わせると, 求める予測量（人口密度）が必ずしも一致 しない，そこで重相関係数が高くても面積の大小に影響 される值がでてきて好ましくないので検討から除外する. そこで都市の面積と都市区域内の線路数とを組み合わせ た予測式に限って検討をすることにする，すなわち，式 (3.1d) は重相関係数も0.953 と比較的高く, 求める定 数は3個であるが，あてはまりが良いので首都圈におけ る衛星都市の飽和人口密度を予測する式とする. 求めた 定数は以下のとおりである.

$$
\begin{aligned}
& A=20912 \\
& B=-0.024686 \\
& C=-0.025991
\end{aligned}
$$

となって

$$
p_{59}=20912 \exp \{-0.024686 \mathbf{t}-0.025991(\mathbf{M} / \mathbf{n})\}
$$

となる.これによって上記37都市の人口密度を基準変量 とし, 式 (3.1) で求めた予測合成変量との相関係数 R は 0.936348 となり，前回発表した数字 $0.922589^{11)}$ より多 少近似度が高くなった。これらの式は統計的に有意の差 があるわけではないが，使い易い式として用いた。これ は前回発表したサンプル数を26都市から37都市に増やし， 通勤圈として遠い所も組み込み，また都心を形成する区 を前回は除外していたが，今回はそれをも考慮して得ら れた数字なので応用範囲は広くなったと考えられる.人 口予測のように社会的現象は実験ができないので，サン プル数が少ないことはやむをえないことと考え，検定統 計量 $\mathrm{t}$ 值を求め確からしさを調べて，応用の可能性を 検討した.

これらの式(3.1)の定数のうち B,C について偏回帰係 数として $\mathrm{t}$ 一分布検定を行うと検定統計量 $\mathrm{t}_{0}{ }^{21)}$ はそれ ぞれ 8.483，7.458となり，有意水準 $5 \%$ の $\mathrm{t}$ 值は自 由度34の2.0336であつて，これより大きく，帰無仮説は 信頼係数 $95 \%$ で衰却される.これによって式(3.1) は 信頼性があると考えられる.

この式(3.1)で求める予測人口密度について首都圈の 他の衛星都市に適合するかを検討する. 東京都の都心に ついては定住人口の流出が著しいが，周辺の衛星都市は 定住人口の増加を見ている. 中間になる都心入口駅の所 在する帯状の区をひとつの区域と見なすと, 一つ一つの 区としては人口の増減があるが全体では増減が少なく， 都心の人口減少区域と郊外の人口増加区域の中間で変動 が少なく，均衡状態にあると考える.そこで都心入口駅 の所在区として品川, 目黒, 渋谷, 新宿, 豊島, 北, 荒 川, 台東, 墨田, 江東の 10 区をまとめて人口の均衡し 飽和人口状態になっている一つの区域と見なして昭和 59年のデータで 式(3.1) の予測值を求め検討をする. 求めた予測值のうち江東区については実際の数值と予測 值との偏差が標準偏差の 3 倍を超えているので外れ值
とし，また式(3.1) を求める際にデータとして用いた目 黒, 政谷，新宿の各区を除いて検討する，飛び飛びには なるがこれらの各区をあわせて一つの帯状の衛星都市と 仮定し, 都心入口駅の所在する区域であるので, $\quad \mathbf{t}=0$ として式(3.1) で予測值を求めると 18833 人 $/ \mathrm{km}^{2}$ とな る. 実際の数值は 17770 人 $/ \mathrm{km}^{2}$ で約 $6 \%$ 大きいが近似 值が得られた. また先の計算では検討するデータとして は考慮期間中に区の編成替えがあるため除外していたが， 区の編成替えの後昭和 59 年ころから定住人口の変動が 少なく飽和状態になっていると見られる横浜市戸塚区に ついて $\mathbf{t}=33$ 分として式(3.1)で人口密度を求めると, 昭和 62 年〜平成 6 年の平均值 6628 人 $/ \mathrm{km}^{2}$ の人口密度 に対して予測值は 6384 人 $/ \mathrm{km}^{2}$ で約 $4 \%$ 小さいが近似 值が得られた.これによって式(3.1)で求めた人口密度 を首都圈における衛星都市の飽和人口密度と想定するこ とが確かめられた.

\section{（2）飽和人口密度の時間的変化}

ここで想定した首都圈衛星都市の飽和人口密度は昭和 49年から昭和59年の間で同じ値とはなっていない. 各年 別に計算をしてみると少ないながらも変化が見られる まず37都市の人口の総合計では多少のゆらぎを伴いなが らも $1 \%$ 程度の増加を示し，ほぼ変化がない状態であ る. しかしながら飽和人口密度の予測式の式(3.1)の定 数項にも変動が見受けられる.

予測式の定数項の A は逆に1年平均で $0.5 \%$ 程度の 减少がみられる. 予測変量として用いた都心到達時間, 1 線路当りの都市面積に対する定数項も少ないながら変動 がある.このことは基本的には都市の飽和人口密度は必 ずしも一定ではなく, 首都圈の定住人口の動きとしては 広さと快適性を求めて居住空間の拡大の方向にあって, そのため人口密度は堿少しているものと考えられる.こ の点については人口密度の変化は共通の曲線にのると仮 定 $^{3}$ ) している研究においても，飽和人口密度が低下寸る 方向に変化したためと説明されている．また人口の社会 増加率の観点から人口密度は平準化されるとして都心部

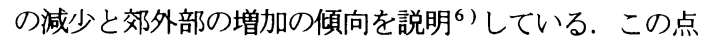
については衛星都市の飽和人口密度が年数の経過ととも に徐々に低下していることに関係があることを示してい る.

この傾向は短期間の予測にはほとんど影響を与えない 程度であるが, 10 年あるいはそれ以上の長期間の予測 になると必ずしも無視できない値となってくるので検討 を行った. 定数項の A は 1 次式で近似させても减衰指 数曲線で近似させても短期間ではあまり変わらないが長 期間を考える予测には時間の経過によってもマイナスと ならない减衰指数曲線で近似させることにする.ほかの 予測変量の定数項の B,C は A に比べ相対的に小さく 
0.0002 から 0.0001 程度であるので, 計算では1次式で 近似させた. ここで予測式の定数項 $\mathrm{A}$ においてでを時 間のパラメーターとして

$$
\mathrm{A}=\mathrm{A}, \exp \left(-\beta \tau^{*}\right)
$$

で示され

$$
\begin{aligned}
& A_{1}=21886 \\
& \beta=0.00574
\end{aligned}
$$

である. また $\mathrm{B}, \mathrm{C}$ については下付添字の記号を定数とし

$$
\begin{aligned}
& B=-B_{1} \tau^{*}+B_{0} \\
& C=-C_{1} \tau^{*}+C_{0}
\end{aligned}
$$

であらわされ,

$$
\begin{aligned}
& \mathrm{B}_{1}=0.000216 \\
& \mathrm{~B}_{0}=-0.02573 \\
& \mathrm{C}_{1}=0.000103 \\
& \mathrm{C}_{0}=-0.02529
\end{aligned}
$$

であって，また $\tau{ }^{*}=0$ は昭和 49 年とする.

定数 $\beta$ について有意水準 $5 \%$ で無相関の検定を行うと 検定統計量 $\mathrm{t}_{0}{ }^{21}$ ) 12.08 となり $\mathrm{t}$ 值は自由度 9 で2.262で あって, 帰無仮説は棄却され, 有意と判定した.

この数值は実際の人口密度のデータから推測するとき に，日本の総人口の伸び率が低下している点や首都圈の 人口集中が徐々に改善されている影響などを含んでいる ことなどを示しているものと考えられ，長期間の予測値 を推定するには有効と考えられる.

\section{（3）人口密度への飽和状態への接近の形}

衛星都市の都心への通勤輸送条件が改善された場合, 都心までの到達時間や区域内の線路数が変化すると飽和 人口密度を定める前提条件が変化することによって沿線 衛星都市の飽和人口密度に変化が起こってくる.この前 提のもとに衛星都市の人口密度はどのような形で飽和人 口密度に接近していくかを調べる. 過去の衛星都市の人 口密度の変遷を見ると, 都心二の輸送改善として線路増 設や新線の建設が行われると，今までの人口の緩やかな 増減の傾向からあるタイムラグを経過して, 突然人口密 度の急激な増加が表れ, 徐々にその増加率が小さくなり ながら，ある極限值として前述の飽和人口密度に接近し ていく.

そこで年次を変数とした函数として人口密度の曲線を 考える. 衛星都市において都心への輸送改善がおこなわ れるまでは，その都市のおかれた条件によってある緩や かな曲線で推移しているが，輸送改善が行われた後には 人口密度の曲線が大きく変化している. 変化の様子を見 ると, 輸送改善がなされて直ちに人口密度の曲線が変化 するわけでなく, 都心に近い衛星都市は比較的に早く増 加に変わり, 都心から離れた衛星都市は遅れて増加に転 ずる現象がある. 輸送条件の改善の他にも社会情勢の変 化の場合にもタイムラグがあり，時間的なずれ22) があ

\section{ることが発表されている.}

人口密度の曲線と類似をしていて，よく用いられるロ ジスティック曲線（2.1)は $\boldsymbol{a}$ の $1 / 2$ で変曲点を有し， 横軸の位置にかかわらわず一定である. 都市が何かの条 件によって急激な人口の増加を来すような場合には人口 密度の曲線の変化はロジスティック曲線には似ているが 都市のおかれた状態によって人口密度の増加率の変化を 示す変曲点は異なっている. 年次毎の人口密度の変化量 をみると, 昭和 40 年代には毎年の人口密度の増加率が 徐々に增加し, やがてピークをむかえ変化が小さくなつ ている.この人口密度の增加率のピークの点がロジス ティック曲線の変曲点に相当するとみなし, 変曲点から は極限值にむかって接近していく成長曲線と仮定して衛 星都市の人口密度を予測する.

この衛星都市の人口密度の成長曲線の変曲点は実際の 増加状況を検討してみると, 多くの都市の人口密度の経 年の曲線ではロジスティック曲線の $\boldsymbol{a}$ の $1 / 2$ の近傍ば かりでなく離れている点でも変曲点となっている．その ため, 衛星都市のおかれた環境によって変曲点の位置の 変動が大きいため, そのままロジスティック曲線と見做 して応用はできない，そこで人口密度の変化量の最大点 をロジスティック曲線の変曲点に相当するものと見做し, その位置とその時点の人口密度の増加率を求め, 前述の 人口密度の成長曲線の極限值を想定ができていることと によって, 衛星都市の人口密度の成長曲線が定められる. 途中の変曲点まで衛星都市の人口密度は近似的に従来 の傾向がそのまま直線として延長されると仮定した. 輸 送改善が行われる以前と以後の人口密度の変化は, 緩や かな変化を示しているため, これらの異なった曲線を連 続させるためにはより複雑な曲線での近似も考えられる が，過渡期間で短時間の変化であることを考虑し簡便な 方法を用いた. この衛星都市の人口密度の変曲点を求め るには，毎年の人口密度の増減量に着目すると曲線で近 似させることは可能な形をしているが左右対称の曲線で はない. そこで, 人口密度の増堿量を 3次曲線に近似を させて経年変化曲線を試算してみた．この 3次曲線の極 大值の年次をもとめて人口密度曲線の変曲点として推定 し人口密度の変化の曲線を最初に求めた。 しかし，人口 密度の5箇年平均をとって求めた変曲点と3次曲線に近似 させて求めた変曲点とは差が少なかったことと, また都 市によっては人口密度の変遷を 3次曲線で近似させると 変曲点が求まらない場合もあるので人口密度の 5 箇年平 均を用いて計算をした。

データとしては昭和 40 年代に輸送改善が行われ，都心 への到達時間が大きく短縮された東北本線, 高崎線, 常 磐線の沿線から大きく離れた数值を示寸都市を除いた 16の衛星都市をサンプルとした. 輸送改善がおこなわれ てから都市の人口密度の急激な変化が表れる変曲点を示 
表-3.2人口密度変曲点関連相関行列

\begin{tabular}{|c|c|c|c|}
\hline & $\mathbf{T}$ & $\mathbf{t}$ & $\mathbf{M} / \mathbf{n}$ \\
\hline $\mathbf{T}$ & 1.00000 & 0.72079 & 0.51227 \\
\hline $\mathbf{t}$ & & 1.00000 & 0.29670 \\
\hline $\mathbf{M} / \mathbf{n}$ & & & 1.00000 \\
\hline
\end{tabular}

す輸送改善からの遅れの年数を $\mathbf{T}$ とし， $\mathbf{t}, \mathbf{M}, \mathbf{n}, の$ 他にいくつかの要素として $p_{59}$, 変曲点における人口 密度の変化量 $\mathbf{V}$ 等を含めて相関行列を求めた.この $\mathbf{T}$

を基準変量とし，求めた相関行列のなかで $\mathbf{T}$ に対して 相関係数の大きい $\mathbf{t}, \mathbf{M} / \mathbf{n}$ を予測変量として重回帰式 を求めるために，表-3.2 人口密度変曲点関連相関行列 を用いた結果，式(3.5)となる.

$$
\mathbf{T}=\mathrm{A} \mathbf{t}+\mathrm{B}(\mathbf{M} / \mathbf{n})+\mathrm{C}
$$

ここに $\mathrm{A}, \mathrm{B}, \mathrm{C}$ は定数であって，求めた数值は

$$
\begin{aligned}
& A=0.19428 \\
& B=0.11345 \\
& C=-5.4405
\end{aligned}
$$

である。

この式 (3.5) のうち定数 A, B について偏回帰係数 として $\mathrm{t}$ 一分布検定を行うと検定統計量 $\mathrm{t}_{0}{ }^{21}$ はそれぞれ 2.925，1.564となる. A については有意水準 $5 \%$ の $\mathrm{t}$ 值は自由度13での2.16より大きく帰無仮説は信頼係数 95 $\%$ で裹却される. 一方 $\mathrm{B}$ は有意水準 $20 \%$ 值が自由 度13での1.350であつて信頼係数 $80 \%$ で棄却される. B の信頼度は少し小さいが有意と判定される.これによっ て式(3.5)は信頼性があると考える.

つぎに変曲点の繸軸の位置は衛星都市によってまちま ちであるので, 式(3.5) で求めた輸送改善から遅れて表 れる変曲点における年度の人口密度を既に述べた1次近 似式から求める. この変曲点から以降の年次については 人口密度の変化量はそれまでの人口密度曲線とは独立の 成長曲線とし，成長曲線の形を定めるために曲線の始点 である予測変曲点における勾配を次によって求める.

この曲線の時間軸を $\tau *$ とし（ここでは3.2章に示す ように暫定的に ${ }^{*}=0$ に昭和49年を用いた），輸送改 善の行われた年を I 年後とし, その $\mathbf{T}$ 年後の I + $\mathbf{T}$ 年に人口密度の変曲点があるものとする．また都市の人 口密度曲線を $\mathbf{P}\left(\tau^{*}\right)$ とし, 変曲点の人口密度を $\mathbf{P}(\mathbf{I}+$ T）とする．また緩やかに変化している都市の飽和人口 密度は $\boldsymbol{p}_{\mathrm{s}}\left(\tau^{*}\right)$ で表す. 前と同様に幾つかの变数を考 えて相関行列を求め, 基準変量として変曲点における変 化量 V の対数 $\log (\mathbf{V})$ をとり, 予測変量として $\mathbf{t}, \mathbf{M}$ /n， $\mathbf{P u}_{\mathrm{u}}$ をとって重相関分析を行った. ここに $\mathbf{P u}_{\mathrm{u}}$ 末飽
表-3. 3 重み付き密度伸び率相関行列

\begin{tabular}{|c|c|c|c|c|}
\hline & $\log (\mathbf{V})$ & $\mathbf{t}$ & $(\mathbf{M} / \mathbf{n})$ & $\log \left(\mathbf{p}_{\mathbf{u}}\right)$ \\
\hline $\log (\mathrm{V})$ & 1.00000 & -0.80317 & -0.52611 & 0.59622 \\
\hline $\mathbf{t}$ & & 1.00000 & 0.29670 & -0.65146 \\
\hline$(\mathbf{M} / \mathbf{n})$ & & & 1.00000 & -0.80651 \\
\hline $\log \left(\mathbf{p}_{\mathbf{u}}\right)$ & & & & 1.00000 \\
\hline
\end{tabular}

和人口密度とし, 輸送改善がおこなわれてから T年を経 過した人口密度の予測変曲点における人口密度 $\mathbf{P}(\mathbf{I}+\mathbf{T})$ とその時点の飽和人口密度 $\boldsymbol{p}_{\mathrm{S}}(\mathbf{I}+\mathbf{T})$ との差 $\boldsymbol{p}_{\mathrm{S}}(\mathbf{I}+\mathbf{T}$ ) 一 $\mathbf{P}(\mathbf{I}+\mathbf{T})=\mathrm{P}_{\mathrm{u}}$ である. $\mathbf{V}$ の予測式として

$$
\mathbf{V}=\mathrm{A} \exp \{-\mathrm{B} \mathbf{t}+\mathrm{C}(\mathbf{M} / \mathbf{n})\} \mathbf{p}_{\mathrm{u}}{ }^{\mathrm{D}}
$$

を用い, この式(3.6)の両辺の対数をとって

$\log (\mathbf{V})=\log (A)-B \mathbf{t}+C(\mathbf{M} / \mathbf{n})+D \log \left(\mathbf{p}_{\mathrm{u}}\right)$

として, 基準変量に $\log (\mathbf{V})$, 予測変量に $\mathbf{t},(\mathbf{M} / \mathbf{n})$, $\log \left(p_{\mathrm{u}}\right)$ として重相関分析をおこなった. ここに

Log ( A ) : 定数, B : 定数, C : 定数, D : 定数 である。

この重相関分析を行う際に，目的とする通勤鉄道の沿 線衛星都市の人口を求めることが目的であるので, 衛星 都市の面積の大きい都市ほど重みが付いていることが望 ましい. そのため重み付きの重相関分析を行った.

まず 表-3.3 重み付き密度伸び率相関行列 が得ら れ，これから求めた定数は次ぎの通りである.

$$
\begin{aligned}
\log (A) & =15.973 \\
B & =0.064626 \\
C & =-0.055995 \\
D & =-0.95840
\end{aligned}
$$

である.

次に, 式(3.7)によって求めた $\log (\mathbf{V})$ を指数変換 して人口密度成長曲線の変曲点における変化量 V ( こでは増加量) を求めた.これらの式(3.7)の定数のうち $\mathrm{B}, \mathrm{C}, \mathrm{D}$ について偏回帰係数として $\mathrm{t}$ 一分布検定を行うと 検定統計量 $\left.\mathrm{t}_{0}{ }^{21}\right)$ はそれぞれ 39.9，19.6，12.9 となり， 有意水準 $5 \%$ の 值は自由度14の2.145であって, こ れより大きく，㷌無仮説は信頼係数 $95 \%$ で萧却される. これによって式(3.7)は信頼性があると考える.

これによって求めた定数によって衛星都市の人口密度 の経年変化を予測することができる.

\section{4. 人口密度の予測}

\section{（1）人口密度の経年変化}

首都圈衛星都市の飽和人口密度を求める際の定数 A 
は短期間では多少の変動があっても，始めは一定と考え たが3.2章で記述したように昭和49年から昭和59年にか けて首都圈全体としては緩やかに減少している．長期間 の予測には無視できない数字となるのでこの点を考える こととする. 都市の人口密度は飽和人口密度に成長曲線 の形で時間の経過に従って接近すると考え，一方この飽 和人口密度は年数の経過に従って指数曲線で変化してい るとする.

まず各衛星都市毎の人口密度の予測値を求める際に基 準点として3.2章と同样に昭和49年をとり， $\tau^{*}=0$ と する. $\tau^{*}=\mathbf{I}$ 年に輸送改善が行われ, その $\mathbf{T}$ 年後

（T は衛星都市によって異なる値を示している）に人 口密度の変曲点が現れるとすると, $\tau{ }^{*}=\mathbf{I}+\mathbf{T}$ 年から 人口密度が急に大きな增加量を示す。ここで改めて $\tau$ * $=\mathbf{I}+\mathbf{T}$ 年を人口密度の成長曲線を求める基準点として $\tau=0$ 年とし, 時系列としてみると, $\tau=-\mathbf{T}$ 年に輸 送改善が行われ， $\tau=-(\mathbf{I}+\mathbf{T})$ 年が予測值を求める際 にもちいたデータの起点となる.これを概念的に示した 図-4. 1 衛星都市成長曲線 を参考にしながら都市の人 口密度の経年の変化は以下のように考える.

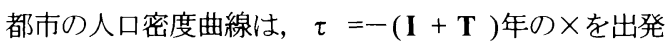
し， $\times \sim \diamond \sim ○ 〜$ を通る太い実線で示し， $\tau \leqq 0$ は直 線 $\mathbf{P}^{\prime}$ とし， $\tau \geqq 0$ は曲線 $\mathbf{P}$ s とする. この曲線は, その 年毎に人口密度の成長曲線の極限值（変化している場合 も変化していない場合も含めて）にたいして指数曲線の 形で接近すると考える. 都市の飽和人口密度が経年で変 化している場合，図の○〜音通る細い実線の曲線であ らわされ $p_{\mathrm{s}}$ とする．飽和人口密度が変化しないと考え る場合は $\bigcirc \sim \triangle O$ 軸に平行な直線で示され $\boldsymbol{p}_{\mathrm{c}}$ とする. 都市の人口密度は起点の $\tau=-(\mathbf{I}+\mathbf{T})$ 年を $\times$ から出 発し, 輸送改善された $\tau=-\mathbf{T}$ 年〉を通過し, 人口密度 の変曲点のあらわれるのまでを直線で近似させる，人口 密度の変曲点 $\tau=0$ 年○以降においては, 第一に飽和 人口密度が変化しない場合と第二に変化する場合とにつ いて考える.

第一の飽和人口密度が変化しない場合, 飽和人口密度 は○〜 $\triangle$ を通る直線の細い点線であらわされる $\boldsymbol{p}_{\mathrm{c}}$ であ

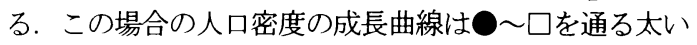
点線で示され $\mathbf{P}_{\mathrm{c}}$ とする. この $\mathbf{P}_{\mathrm{c}}$ は成長曲線の形で時 間の経過に従って $\boldsymbol{p}_{\mathrm{c}}$ に接近寸る. 第二の飽和人口密度 が変化する場合, 変化する飽和人口密度 $\boldsymbol{p}_{\mathrm{s}}$ は○〜音を 通る細い実線の緩い曲線である. この場合の人口密度の 成長曲線 $\mathbf{P}_{\mathrm{s}}$ は 〜西でされ， $\boldsymbol{p}_{\mathrm{c}}$ に接近する $\mathbf{P}_{\mathrm{c}}$ と同 じ割合で 極限值である $\boldsymbol{p}_{\mathrm{s}}$ に接近するものとする.

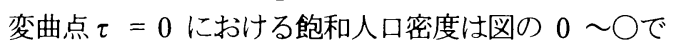
あってこの時の $\boldsymbol{p}_{\mathrm{s}}$ の值を $\boldsymbol{p}_{\mathrm{c}}$ とする. また都市の人口 密度は $\tau=0$ においては $\mathbf{P}^{\prime}=\mathbf{P}_{\text {s }}$ であって $\quad 0$ のの

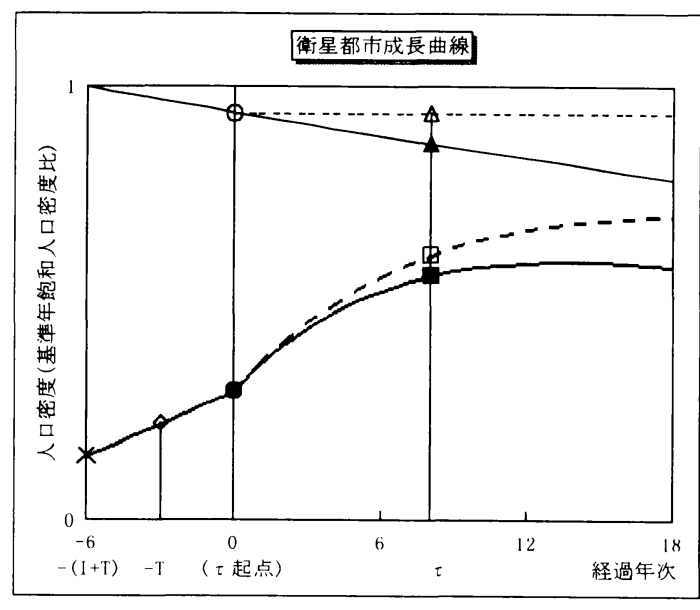

図-4. 1 衛星都市成長曲線

值を $\mathbf{P}_{0}$ とする. 変曲点から $\tau$ 年たった場合, 変化しな い飽和人口密度は 0 ○で $\boldsymbol{p}_{c}$ とし, 变化する飽和人口 密度は $0 \sim \boldsymbol{\Delta}$ で $\boldsymbol{p}_{\mathrm{s}}$ とする. また飽和人口密度が変化し ない場合の都市の人口密度は $0 \sim \square の \mathbf{P}_{\mathrm{c}}$ であり, 変化 する場合は 0 〜田で $\mathbf{P}_{\mathrm{s}}$ である. 式(3.2) を参考にして $\boldsymbol{p}_{\mathrm{c}}=\mathrm{A}_{1} \exp (-\beta(\mathbf{I}+\mathbf{T})) \exp (\mathrm{B} \mathbf{t}+\mathrm{C}(\mathbf{M} / \mathbf{n}))$

$\boldsymbol{p}_{\mathrm{s}}=\mathrm{A}_{\mathrm{l}} \exp (-\beta(\mathbf{I}+\mathbf{T}+\tau)) \exp (\mathrm{B} \mathbf{t}+\mathrm{C}(\mathbf{M} / \mathbf{n}))$

$$
\mathbf{P}_{c}=\boldsymbol{p}_{c}-\left(\boldsymbol{p}_{c}-\mathbf{P}_{0}\right) \exp (-\mathrm{b} \tau)
$$

である.

また前述の仮定より

$$
\boldsymbol{p}_{\mathrm{c}}: \boldsymbol{p}_{\mathrm{s}}=\mathbf{P}_{\mathrm{c}}: \mathbf{P}_{\mathrm{s}}
$$

が成立するものとする. これを $\mathbf{P}_{\mathrm{s}}$ について解くのであ

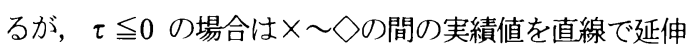
してメ〜のを一次式とする. $\tau \geqq 0$ の場合は以下のよう に考える.

B t + C (M/n) の係数 B,C は式 (3.3),(3.4)に示才 ように変化が少ないので定数とみなして $\mathbf{P}_{\mathrm{s}}$ 求め, 次の 式となる.

$$
\mathbf{P}_{\mathrm{s}}=\exp (-\beta \tau) \boldsymbol{p}_{\mathrm{c}}-\left(\boldsymbol{p}_{\mathrm{c}}-\mathbf{P}_{0}\right) \exp ((-\mathbf{b}-\beta) \tau)
$$

ここに b は変曲点における人口密度成長曲線の係数 V/p p である. $\mathbf{p}_{\mathrm{u}}$ は 3.3章に示す末飽和人口密度である.

ここで首都圈の衛星都市が社会的な条件の変化として, 鉄道線路の新設, 増設, 運行速度の向上といった輸送改 善が行われた場合, 衛星都市の人口密度が年数の経過に 従って増加する人口密度曲線を求めることが可能である.

\section{（2）飽和人口密度の予測式による実例計算}

常磐線沿線の各衛星都市を例にとり, 実際の人口の変 
遷と予測式による值を求め比較をした.

通勤鉄道においてもつとも通勤旅客の多いのは都心の 入り口駅付近であつて，通勤鉄道の輸送設備の規模を支 配する区間で，鉄道建設計画上もつとも注目される区間 である. 常磐線のそれに相当する最も混雑する区間は松 戸・北千住間であることを考慮すると，東京都を離れた 千葉県と茨城県の常磐沿線の都市の人口の動きが予測の 上で必要となる，これを計算してまとめたものが，図-4.2 常磐沿線人口予測 である。 また代表的な数値につい て示しているのは 表-4.1 常磐沿線人口予測抜粋 であ

る. 図-4.2，表-4.1 は双方とも次ぎの 4.3 章のスピー ドアップをした場合の予測值もあわせて記載してある.

ここでは表示はしないが，常磐線沿線の東京都区内 （荒川，足立，葛飾）は 3 区をひとつでまとめて見る と人口総数には変化が少なく, 人口密度は緩やかな変化 で上下をしていると見做され，鉄道建設計画の上では変 化がないものとして扱える.

これによって首都圈の通勤・通学鉄道の輸送改善の際 にスピードアップを図らない場合とスピードアップを 図った場合の沿線衛星都市の人口予測の経年変化の違い が予測できる.

\section{（3）能和人口密度の予測式による応用計算}

本研究では首都圈の通勤・通学輸送鉄道の投資効果を 予測するために，鉄道運行速度の向上がどのように寄与 するかの予測をすることを目的とする．そこで輸送改善 としての線路増設と鉄道運行速度の向上がなされている 常磐線北千住・牛久間を例として取り上げ，輸送改善の 効果を沿線人口の増加数で調べる. 以前に発表した常磐 線の輸送改善としてスピードアップが標淮軌間並みにで きた場合を仮定して沿線の人口がどのように変化するか を計算を行った. スピードアップは都心入り口駅として の日暮里から牛久までで現行の54分から46分と8 分の短 縮を想定した。昭和39年から昭和59年までの間の常磐線 沿線の千葉県と茨城県牛久市までの実際の人口の動きと 予測式による予測人口である予測数"とスピードアップ をはかった場合の予測人口である予測数“*を一覧にする と 図-4.2 常磐沿線人口予測 表-4.1 常磐沿線人口予 測抜粋 のようになる。図-4.2 では昭和54年以前はグラ フ表示では重なって見えるので省略した. これをみると スピードアップによって常磐線沿線の千葉茨城両県の人 口は, 輸送改善の行われた後, 徐々に人口の増加がみら れ，10年後には1\%程度の増であっても28年後には5\% 程度の増となり，以後はさらに差が開いていく．これは 通勤鉄道のスピードアップが沿線居住人口の増加をもた らし，さらには通勤圈の拡大により利用客の増加が十分 に期待されることを示している.この鉄道運行速度の向 上による沿線人口の差について検討をする. 常磐線の輸

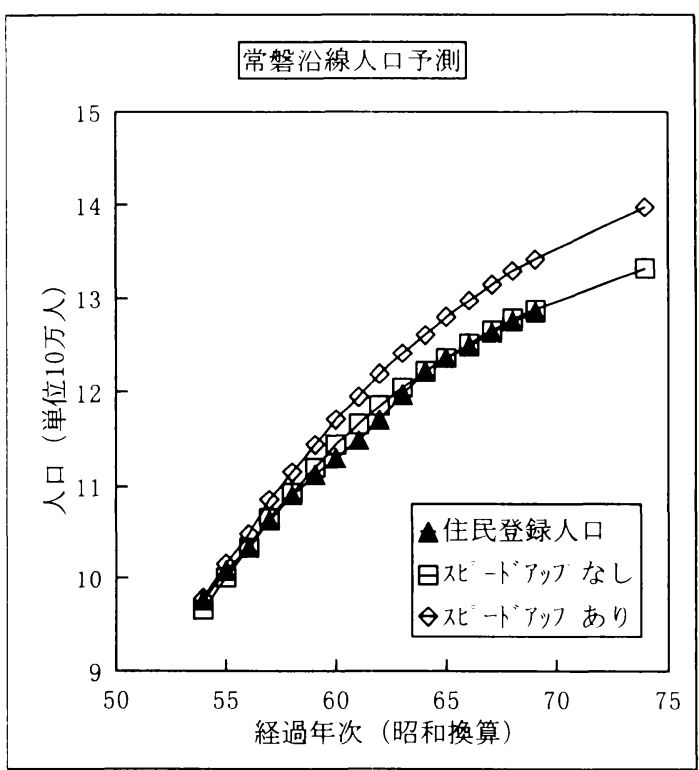

図 4.2 常磐沿線人口予測

表 4.1 常磐沿線人口予測抜粋

\begin{tabular}{|c|c|c|c|}
\hline 年 次 & 住民登録数 & 予測数 ${ }^{*}$ & 予測数 ${ }^{* *}$ \\
\hline 昭和 39 年 & 376151 & 345482 & 350681 \\
\hline 昭 和 44 年 & 540156 & 549157 & 549364 \\
\hline 昭和 49 年 & 770625 & 766718 & 770397 \\
\hline 昭和 54 年 & 975513 & 966941 & 979377 \\
\hline 昭和 59 年 & 1109982 & 1117906 & 1143371 \\
\hline 平成 元 年 & 1220538 & 1220744 & 1260491 \\
\hline 平成 6 年 & 1285768 & 1287829 & 1342091 \\
\hline 平成 11 年 & & 1331063 & 1396452 \\
\hline
\end{tabular}

送改善からのタイムラグを経過し沿線の全都市の人口密 度が急激に増加に転じ，それまでの経過と違った状態に なった昭和59から平成 5 年までの 10 年間について母回 帰の区間推定21)を行った。居住人口の増加が実際の人 口（住民登録人口）の変遷とスピードアップを考えた場 合の予測人口の変遷をみると, 両者とも多少上に凸の形 ではあるが, いくらかの偏差をもってほぼ直線とみなさ れる.この両者について回帰式を求め，それにたいする 偏差が正規分布をしていると仮定して，95\%信頼限界 を求めた，その結果，実際の人口の変遷の母回帰式の上 限とスピードアップを考えた場合の予測人口の変遷の母 回帰式の下限とは互いに交差をしていないことから有意 の差があるものと考えた。 


\section{5. 結論}

通勤鉄道の都心叭到達時間の短縮が沿線の居住人口 にどの程度の影響をおよぼすかを数量的に把握するため に，都心への到達時間および他のにいくつかの要因を用 いて相関分析法の重相関分析を適用することによって, 十分に実用にたえられる数值を求めることができた.

成長過程にある都市において，どのように人口密度が 年毎に変化していくかについては，単純にロジスティッ ク曲線を適用することは問題があるため, 飽和人口密度 という概念を導入することによって沿線衛星都市の人口 密度の変化の様子が実情によくあって説明ができること を示している．またこの飽和人口密度も都市に与えられ た条件の変化や社会情勢の変化によっても，変化してい ることを表している.これらの条件を加味して解明され たこの手法を用いて通勤鉄道のスピードアップが沿線都 市人口の増加から利用客の増加を数量的に把握し，通勤 鉄道のスピードアップが鉄道の経営におよぼす効果を数 量的に求めることが可能になった. 今後は鉄道運行速度 の向上が沿線の人口の増加と輸送量の増加を数量的に予 測することによって，鉄道の設備投資の採算性の予測を 究めたい.

謝辞: この研究には日本鉄道建設公団から各種の貴重 なデータの提供を受けたことに謝意を表すと共に信州大 学奥谷教授のご指導と金沢大学の松浦教授に色々なご教 示を受けたことに深く謝意を表すもである。

\section{参考文献}

1) 秋元伸裕, 原田 昇, 太田勝敏, 新谷洋二:密度関数 による東京大都市圈の通勤 O D 分析, 第25回日本 都市計画学会学術研究論文集, pp.19-22, 日本都市 計画学会, 1990

2) 天野光三, 青山吉隆, 藤田昌久: 都市人口分布形態 に関する情報理論的研究, 土木学会論文集, No.142, pp. $31-36,1967$

3) 古藤 浩, 腰塚武志: 首都圈における人口増加の分析, 第25回日本都市計画学会学術研究論文集,pp.356360 , 日本都市計画学会, 1990.

4) 中川大, 西村寿治, 波床正: 鉄道整備が市町村人 ロの変遷に及ぼしてきた影響に関する実証的研究, 土木計画学研究・論文集, No.11, pp.57-64, 1993.
5) 北鄉 繁: Logistic Curve による人口統計, 土木 学会論文集, No.36,pp.58-63, 1956.

6) 西川智: 都市人口変動の実態と人口密度, 第17回 日本都市計画学会学術研究発表会論文集, pp.25. 30 , 日本都市計画学会, 1982.

7) 住民登録に基ずく全国世帯数表: 法務省民事局, 1964以降.

8）住民基本台帳に基ずく全国人口・世帯数表人口動 態表: 自治省行政局, 1968以降.

9) 東京都の昼間人口: 東京都, 1970, 1975, 1980 .

10) 最新都市計画用語事典: 都市計画用語研究会, ぎょ うせい, p.16, 1994

11) 柴垣 寛: 通勤鉄道の時間短縮が沿線人口に及ぼす 影響の研究, 土木計画学研究・講演集 15(1),pp425-430, 1992

12）時刻表:日本国有鉄道，1964，1984.

13) 奥平耕造: 通勤輸送からみた住宅地の人口密度分布 と発達に関する研究，日本建築学会論文報告集，第 145 号, pp. 54-64, 1968.

14) 小林竜一：需要予測の数学, pp.85-92, 至文堂, 1967.

15) 全国市町村要覧: 自治省行政局振興課, 1964

16) 砂原善文：連続と離散一 [ 1 ] , 計測と制御, Vol.27, No.9, pp.41-49, 計測自動制御学会, 1985 .

17) 山口昌哉：カオスとフラクタル, pp.56-86, 講談 社, 1994 .

18）廣松 毅, 浪速貞夫：経済時系列分析, pp.221-222, 朝倉書店, 1990 .

19）川上洋司，大塚全一，藤倉規雄: 郊外鉄道駅周辺に おける道路網形態と居住人口密度分布の関係につい て, 土木計画学研究・論文集, No.2, pp.77-84, 1985

20）芝 祐順：相関分析法, pp.117-134, 東京大学出 版会, 1982

21) 久米均, 飯塚悦功: 回帰分析, pp.48-50, 岩波書 店, 1996 。

22 ) 天野光三, 藤田昌久: 都市人口密度分布の成長過 程に関する研究，土木学会論文集，No.143,pp.16$21,1967$.

（1995. 5. 20受付） 


\section{A STUDY OF THE SATELLITE CITY'S DIFFERENT POPULATION BY COMMUTATION TIME}

Hor os hi SH B AGAK I

This study is to analyze the governing factors using the regression analysis method to conclude that the shortening of the commutation time can con tribute to the population increase of the satellite cities. Population density of satellite cities within the area are closely related to the trip time from the satellite cities to the business center of Tokyo. The population densities of the cities are depicted by using the exponential distribution curve.

The commutation time is one of the most important factors which governs the population distribution curve. However the other factors affect the curve considerlably. This study got desirable consequence by applied regression analysis method. 